\title{
Dynamic Asymmetry and Converging Threats ${ }^{1}$
}

\author{
Zoltán BÁCS ${ }^{\circ}$
}

Terrorism is changing its paradigm. The superb adaptive capability and the diversification of the methods of financing terrorism give the chance to infiltrate into the political establishment of the most vulnerable countries. The terrorist and the criminal syndicates as allies have common methods, common structures but never merge their organisations. Their strategic goals remain different.

Keywords: asymmetric methods, dynamism, harmonisation of tasks, structured cooperation, transnational organised crime, narco business

\section{Introduction}

When unusual expressions like asymmetry, dynamism and convergence emerge, one hesitates how he or she should understand these notions beyond mathematics and physics. What these words refer in the context of terrorism and counter-terrorism? What are the characteristics of a situation where the permanently on-going changes of the correlations between these notions play a highly important role and determine political, economic and social processes not only in the given society but also far beyond that?

This study intends to give a limited picture of the changes already occurred and going on today in the field of terrorism during the last fifteen years. Due to the permanent transformations and adaptations of the terrorists' modus operandi and paradigm on the one hand and tactics and counter-measure of the counter-terrorist forces on other, the study is rather based on the perceived phenomena, conclusions about the possible tendencies, made by experts, discussions of professionals in this field, than academic publications. However, there are many different academic materials, publications and articles of renowned authors worldwide, whose long experience and authority in the matter is undisputable. The goal is clear: to present the evolution of terrorism in the context of its recent changes and - following the palpable tendencies - to advert the forthcoming threats. To raise awareness of all the social groups including the most vulnerable ones is also an important goal of the present study.

1 The present publication was presented in oral form on the "South America, South Europe International Conference” at the Ludovika University of Public Service, Budapest, Hungary, on 17 April 2021.

$2 \mathrm{PhD}$, lecturer at the National Security Institute of the University of Public Service, Budapest, Hungary, e-mail: bacszgyorgy@gmail.com 
The methods used in this study follow the complexity of the topic combining the comparative analysis of the analogue patterns in the evolution of different fields of criminal activities like organised crime, drug-related crime and terrorism with the analysis of probabilities of the possible consequences in high priority fields like economy and policy-making.

The study is composed of several parts. The first part after the introduction highlights the present conditions in terrorism. After that, the next part focuses on the convergence of the criminal organisations, logically leading to the next part dealing with convergence between organised crime and terrorism.

The next part is about other fields of convergence threatening different levels of policymaking beginning from the local up to the much higher levels. In this chapter, one can find a short retrospective view on the historic background of convergence of the organised crime with politics in the United States of America in the 1930s and its linkage to the new fields of criminal activities in the present days.

The following part deals with one of the most essential fields of crime, i.e. financing terrorism and terrorist organisations. Acts of this kind are criminalised by the penal codes of the majority of countries.

The conclusion - as usually does - summarises what the previous parts dealt with. It underlines the most important features of the convergences paying a special attention to the characteristics separating organised crime from terrorism. The conclusion also reiterates the ultimate threat for the democratic societies, the hardly visible, slow penetration of terrorism in the societies through the most vulnerable social groups.

\section{Actual conditions and circumstances}

As one follows the facts and as terrorism is changing in different ways in different regions of our planet since it was downed in the battlefields by the military forces, some new phenomena have come up to the surface related to terrorist organisations. ${ }^{3}$ At first sight, some of these phenomena are far from being related to financing terrorism. They cover issues of logistics, markets to be used to finance the terrorist organisations' activities, the oscillations between the offers and demands of different merchandises and services, labour force related issues, economic features and/or the technical background of the production of fast-moving consumer goods, mostly household appliances and electronic items. Although these things seem peripheral, they play an important role in financing terrorism under the new conditions. What kind of conditions do we speak about?

It is obvious that the terrorism of the $20^{\text {th }}-21^{\text {st }}$ centuries has no continental limits. It has only continental specialties within the global phenomenon called terrorism. It means that terrorism is a present and clear threat not only in the target countries but even in those states which did not suffer violent terrorist attacks on their territories. Since terrorism is not an autochthonous phenomenon, it has to be a research object in

U.S. Government Publishing Office, ‘A Dangerous Nexus: Terrorism, Crime, and Corruption', Hearing before the Task Force to Investigate Terrorism Financing, 21 May 2015, U.S. House of Representatives. 
the global context of international correlation of political, economic and military forces, capabilities and interests as well as international organised crime. "During a hearing in the United States' Senate in 2015 it was stated: “The Director of National Intelligence, James Clapper, identified terrorism and transnational organized crime as among the top eight global threats to U.S. national security when he testified this past February before the U.S. Senate's Committee on Armed Services. According to Director Clapper, both terrorist and transnational criminal groups thrive in highly insecure regions of the world, with terrorist groups contributing to regional instability and internal conflict, while transnational organized crime groups exploit these environments for financial gain and corruptive influence."4

One of the key elements of the operational capabilities and survival of terrorism is the use of asymmetric methods. ${ }^{5}$ Terrorists are highly mobile, flexible and resilient, they have well-structured networks, thus they have a certain tactical advantage against the counter-terrorism forces which design their counteractions on the already received information from different sources ranging from civilians to intelligence data. It is clear that the gap between real time information and information received after a certain time affects the probability to prevent any crime including terrorist attacks. Terrorists widely use asymmetric methods, beginning from the background checking of the potential recruits, the recruiting process, the planning of operations, financing, procurement of weapons, explosives, vehicles, clothes, different auxiliary materials and services, selection and training of perpetrators up to the appointment of alternative targets and methods of perpetration. Seemingly, this dynamic asymmetry is the key element of the successful terrorist acts; this is the way to use the tactical advantage by changing the methods and keeping them dynamic. The aim of the dynamically changing operational and network-keeping factors is nothing but to prevent the success of counter-terrorism and national security forces. Another feature of the advantage given to the terrorists by asymmetric dynamism is that their steps do not need to be coordinated in details with their superiors while all the measures to be taken by the law enforcement, national security and counter-terrorism services require coordination and planned operations with the superiors and have to be implemented according to the existing protocols within the law.

\section{Convergence among the criminal organisations}

What converges to what? The cross-border links of organised crime - especially in the field of drug-trafficking, trafficking of humans, weapons and other merchandises - and terrorism have a common feature: the complexity, which means horizontally and vertically structured planning and the implementation and timing of measures, building one level upon the other. ${ }^{6}$ If we take an example from the economic cooperation, the convergence is

\footnotetext{
4 Ibid.

5 See István Resperger, Álmos Péter Kiss and Bálint Somkuti, Aszimmetrikus hadviselés a modern korban. Kis háborúk nagy hatással (Budapest: Zrínyi, 2014); József Padányi, ‘Az aszimmetrikus hadviselés során alkalmazandó eljárások, eszközök és módszerek’, Hadtudomány 25, no 1-2 (2015), 81-82.

6 U.S. Government Publishing Office, 'A Dangerous Nexus’.
} 
a natural process based upon the vertical harmonisation of the separate phases, depending on how complicated the next phase is and which level of combination and harmonisation is required for its successful implementation.

We see the same in the world of the transnational organised crime and terrorism. The coincidence of the tactical interests, the material advantages and in case of terrorism, the need to obtain the tools for the implementation of the political intentions generates a 'natural', sometimes strategic cooperation between the groups and organisations specialised in different kinds of criminal activities. Thus, the different kinds of criminal activities are to be implemented complementing each other for common tactical goals. Due to the fact that the organisational background keeps being separated, there is no fusion between the criminal organisations. They only converge towards each other in their functions. Therefore, we can state that there is a functional convergence between different criminal organisations.

\section{Convergence and terrorism}

Terrorism, as a special form of contemporary organised political crime, is also special from the point of view of convergence. As we have already seen, the tactical cooperation with criminal organisations in the preparation of terrorist acts is a common practice of terrorist organisations. At the same time, there is a special field, an extremely dangerous area of the transnational organised crime, where the strategic sectoral convergence is imminent. This covers transnational drug-related crimes and the financing of terrorism. In this case the creation of the material and financial background for financing the functioning of the organisation and the terrorist acts is the common interest what motivates the permanent and solid relations between the organisations. The consequence is that many of the terrorist organisations are active in the drug business, their activities ranging from production via trafficking, to protection of the plantations and the laboratories. Of course, everyone will think about the Colombian Revolutionary Armed Forces (Fuerzas Armadas Revolucionarias de Colombia, FARC) and the Shining Path (Sendero Luminoso) of Peru, but it is also important to be aware of the fact that it is the Hezbollah, which holds in its hands the production of Captagon, amphetamines and methamphetamines in the Middle East. $^{7}$

Further processing, refining and transporting the drugs to the markets and the sale is entirely the task of the criminal groups specialised in these activities.

Robert Charles, former Assistant Secretary of State, responsible for international drug and law enforcement affairs, also confirmed the convergence between the world of terrorists and international organised crime. ${ }^{8}$ Another high ranking expert, Dennis Lormel, head of the department of the FBI dealing with financial crimes, said that organised criminal

Ibid.

$8 \quad$ Frank S Perri, Terrance G Lichtenwald and Paula M MacKenzie, 'Evil Twins: The Crime-Terror Nexus’, Forensic Examiner 18, no 4 (2009), 16. 
groups assist terrorist organisations in obtaining the necessary funds. ${ }^{9}$ According to the list of the Drug Enforcement Agency (DEA) more than half of the forty-one terrorist organisations on the list maintain relations with drug syndicates. ${ }^{10}$ Since 2004, when the statements above were made, the statistics have changed only a little. Actually, there are 72 designated terrorist organisations on the list of the State Department, among them there are more than three dozen involved in the narco business. ${ }^{11}$ The tendencies of the past years confirm the forecast in the report prepared by the Federal Research Division of the Library of the United States Congress in 2002. ${ }^{12}$

If we look at the whole picture, we might notice how the levels of convergence are built upon each other. At the basic level, the organisations complement each other resulting in crimes converge. On the next level, crime syndicates acting on different sides of the border establish converging cooperation, and at the top level, we see the convergence between international organised crime and terrorism.

\section{Another field of convergence}

There is another structured field of convergence, too. Some of its bases have already been touched upon in this writing. The local covert enterprises used for money laundering, confessional and cultural schools, sport clubs and charity groups exercise influence on the most vulnerable social groups, approaching through them the local political, economic, cultural, sport and religious organisations as well as the representatives of local administration and legislation. The goal of the terrorist organisations hiding behind these covert enterprises is the infiltration, penetration and integration into the local bodies of power in order to gain influence there. They do it in the most acceptable way, observing the legal frameworks, holding the appearance of legally operating companies and organisations whereas in fact a terrorist organisation is converging with the power behind the curtains - for the time being, at the local level. ${ }^{13}$

Terrorism in many places, in several countries of Latin America and not only, has already converted into political forces and factors of power, thus it has become a threat for the national security of the affected states. The secret, why terrorism is so viable, lies in its adaptive capability. It can adapt rapidly to the changing circumstances and conditions; it can change its own 'profile'. Terrorism - facing the new circumstances - will find the more profitable conditions, the ways, how to take advantage for its survival and extend its influence on the organisation under the new rules. Terrorism will profit from the social

$9 \quad$ U.S. Government Printing Office, 'Three Years after September 11: Keeping America Safe. U.S. Senate Committee of Justice', testimony of Denis M Lormer before the Senate Judiciary Committee, Subcommittee on Technology, Terrorism, and Government Information, 2003, 61-64.

10 Ibid.

11 U.S. Department of State, 'Foreign Terrorist Organizations’, Bureau of Counterterrorism, s. a.

12 See The Library of Congress, 'A Global Overview of Narcotics-Funded Terrorist and other Extremist Groups'. A Report Prepared by the Federal Research Division, Library of Congress under an Interagency Agreement with the Department of Defense, May 2002, 1-2.

13 Ibid. 
and economic problems of the most vulnerable social strata, of the dysfunctions of the political, social, cultural institutions and will use them to achieve its strategic goals.

If we consider these ideas from the point of view of organised criminal activities, we will see a similar situation. It is not a new phenomenon in the organised crime's world. In the 1930s, when big organised crime syndicates in the U.S. realised that the bloodshed was not good for the business for it estranged profitable activities and possible partners, they opted for reconciliation and the splitting up of zones of influence and types of crimes. The result was imminent: the adaptation and integration of the legally opened enterprises covering the criminal organisations into the economic, social, cultural, labour and not the least, the political structures of the country. Moreover, there are other common features between the two illegal crime complexes and the perpetrators. Both groups pursue illegal activities which are to be sanctioned by law, both use extreme violence including kidnapping, hostage taking, homicide, extortion, arson, corruption and bombing. During the last decade some new types of crimes have also appeared. Among them, it is worth mentioning the crimes through computer networks causing material, financial damages and losses affecting or destroying computational systems, databases, etc. This is the realm of the cybercrimes.

Both organisations, terrorist groups and organised crime, have a horizontally and vertically well-structured organisational system with clear subordination, high discipline where the commands of the superiors are implemented strictly. Both organisations have well-equipped and trained paramilitary structures with intelligence, reconnaissance, counter-intelligence, analytics and assessment, operational, logistic and IT capabilities. Another important point is that both organisations have a very wide and efficient international connection network. These connections are used for different purposes by the different organisations. ${ }^{14}$ Organised crime syndicates use them to support the core business activities while terrorist organisations use them for the creation of the indispensable conditions for their core activity, the perpetration of terrorist attacks. ${ }^{15}$ In both cases the activities through the transnational connections include the acquiring of financial funds, purchasing of weapons, explosives, services, trafficking of drugs, weapons, humans - illegal migrants and potential perpetrators as well, and money laundering.

The terrorist acts in Brussels and Paris of 2015 and 2016 are the best examples of the interconnected transnational network activities. The modus operandi in Paris was very much like the terrorist acts perpetrated in 2008 in Mumbai, where ten terrorists with submachine guns and explosives massacred 164 people. According to the Time, this attack gave the idea to the Paris attacks. ${ }^{16}$ Purchasing the handguns was not a problem since in the Western Balkans there are 3 to 6 million (!) units of these weapons. ${ }^{17}$ In connection with

14 See Zoltán György Bács, Terrorizmus és kábítószer-kereskedelem Latin-Amerikában 1980 és 2019 között (Budapest: Nemzeti Közszolgálati Egyetem, 2020).

15 See also Boaz Ganor and Miri Halperin Wernli, 'The Infiltration of Terrorist Organizations Into the Pharmaceutical Industry: Hezbollah as a Case Study’, Studies in Conflict and Terrorism 36, no 9 (2013), 699-712.

16 Naina Bajekal and Vivienne Walt, 'How Europe’s Terrorists Get Their Guns?’, Time, 07 December 2015.

17 Ibid. 
the Paris attacks, Christophe Crépin, the representative of the French Police Syndicate said: "There is connection between organized crime and terrorists." 18

\section{Transmission of funds}

Both crime syndicates and terrorist organisations widely use the methods of transmission of values and financial means and obligations based upon IT solutions. The traditional transmission of money in cash is based upon couriers or the 'hawala' system or banking transactions, ${ }^{19}$ but terrorists use a higher level of FinTech methods for transferring money in small amounts. For these purposes they can use the 'Simple' application or the Revolut and the Transferwise.

It is more than shocking to see the amounts of money criminal organisations with Latin American connections move illegally in a year. The best example is the case of the HSBC Bank. Through this bank the Mexican Sinaloa cartel and the Colombian Norte del Valle cartel laundered 881 million U.S. dollars clean. Through the HSBC Bank, the Mexican crime syndicates yearly transfer 19 to 31 billion (!) U.S. dollars illegally. ${ }^{20}$

Among the contemporary solutions one can find the virtual means as well, including crypto-currencies, like bitcoins, the electronic payment services operating on the cellphone networks, like PayPass, or the M-Pesa system and the Prepaid cards. Salah Abdeslam and Abdelhamid Abaud, the perpetrators of the Paris terrorist attacks on 13 November 2015 also used prepaid cards. ${ }^{21}$ Celina Realuyo in her study draws attention to a peculiar novelty. The implementation of the illegal banking transactions through the dark web is becoming more and more similar to the exchange operations, where 'couriers' operate between the sides interested in the exchange or investment, searching and finding the appropriate and reliable partners according to the requests and information transmitted to them earlier. ${ }^{22}$ From the point of view of the "black" exchange market it does not matter whether the business without requiring direct contact is done between criminal syndicates and terrorist organisations. This solution helps to occult the identity of the partners thus reducing the risk of deconspiration.

The difference between terrorist organisations and organised crime groups is mostly in the motivation. Organised crime is interested in the maximum material or financial benefits for what it uses the means described earlier. In case of terrorist organisations, the motivation is political, to gain power. ${ }^{23}$

18 Ibid.

19 UN Security Council Counter-Terrorism Commission, 'Paris attacks showed role of small transactions in terror finance; UN meeting hears’, 15 April 2016.

20 Celina B Realuyo, “"Siguiendo el rastro del dinero” para combatir el terrorismo, el crímen y la corrupción en las Américas’, in El crímen orgnizado en América Latina: manifestaciones, facilitadores y reacciones, ed. by Carolina Sampó and Valeska Troncoso (UNED: Instituto Universitario General Gutiérrez Mellado, 2017), 192-193.

21 Kimberley L Thachuk and Rollie Lal (eds), Terrorist Criminal Enterprises: Financing Terrorism through Organized Crime (Praeger Security International, 2018), 51.

22 Realuyo, “"Siguiendo el rastro del dinero”, 196.

23 Boaz and Halperin, 'The Infiltration of Terrorist Organizations', 699-712. 


\section{Conclusion}

The similarities and differences described in this study make clear that the link between organised crime groups and terrorist organisations is narco business. This kind of illegal activity does not depend on whether the participants are non-state actors, or proxy groups linked to state actors or different structures related to governmental bodies or national security services through their covert enterprises. The difference is the following: when a state actor participates in the narco business it may be qualified as outbound state terrorism or covert operation within the asymmetric warfare. Obviously, in the given case the foreign state follows far-going political goals in the target country. The states in trying to extend their influence over other entities of the international law often use some proxy organisations to keep the blame in case of deconspiration of the operation far away from their boundaries.

The terrorist organisations also pursue political aims. These conglomerates as nonstate actors neither subjects of international law are not bounded by any legal or moral commitment. Their goals vary depending on the target country. On the one hand, the terrorists might aim to constitute their own statehood by taking over the power in a weak state hardly capable and governable to resist the terrorists' violent warfare. On the other hand, they might intend to overtake the power and systematically increase their influence on local decision-makers first and widening the range of their interest gradually through other levels of power. The convergence of the terrorist organisations with the legal political system is the major strategic threat. The cooperation and convergence of terrorist groups with the organised crime syndicates including the narco cartels is an important and indispensable step on the way of the terrorist organisations approaching to their goals which means a higher level of security threats for the international community.

\section{References}

Bács, Zoltán György, Terrorizmus és kábítószer-kereskedelem Latin-Amerikában 1980 és 2019 között. Budapest: Nemzeti Közszolgálati Egyetem, 2020. Online: https://m2.mtmt.hu/ gui2/?mode=browse\&params=publication; 31902991

Bajekal, Naina and Vivienne Walt, 'How Europe’s Terrorists Get Their Guns?’ Time, 07 December 2015. Online: https:/time.com/how-europes-terrorists-get-their-guns/

Boda, József, ‘A terrorizmus rövid története és az ellene való fellépés lehetőségei’. Rendvédelem-történeti Füzetek 13, no 16 (2007), 46-51.

Ganor, Boaz and Miri Halperin Wernli, 'The Infiltration of Terrorist Organizations Into the Pharmaceutical Industry: Hezbollah as a Case Study'. Studies in Conflict and Terrorism 36, no 9 (2013), 699-712. Online: https://doi.org/10.1080/1057610X.2013.813244

Padányi, József, ‘Az aszimmetrikus hadviselés során alkalmazandó eljárások, eszközök és módszerek’. Hadtudomány 25, no 1-2 (2015), 81-82. Online: https://doi.org/10.17047/ HADTUD.2015.25.1-2.81 
Perri, Frank S, Terrance G Lichtenwald and Paula M MacKenzie, 'Evil Twins: The Crime-Terror Nexus’. Forensic Examiner 18, no 4 (2009), 16-29. Online: www.ojp.gov/ncjrs/virtuallibrary/abstracts/evil-twins-crime-terror-nexus

Realuyo, Celina B, ““Siguiendo el rastro del dinero” para combatir el terrorismo, el crímen y la corrupción en las Américas’, in El crímen orgnizado en América Latina: manifestaciones, facilitadores y reacciones, ed. by Carolina Sampó and Valeska Troncoso. UNED: Instituto Universitario General Gutiérrez Mellado, 2017.

Resperger, István, Álmos Péter Kiss and Bálint Somkuti, Aszimmetrikus hadviselés a modern korban. Kis háborúk nagy hatással. Budapest: Zrínyi, 2014.

Thachuk, Kimberley L and Rollie Lal (eds), Terrorist Criminal Enterprises: Financing Terrorism through Organized Crime. Praeger Security International, 2018. Online: https:// products.abc-clio.com/abc-cliocorporate/product.aspx?pc=A5619C

The Library of Congress, 'A Global Overview of Narcotics-Funded Terrorist and other Extremist Groups'. A Report Prepared by the Federal Research Division, Library of Congress under an Interagency Agreement with the Department of Defense, May 2002. Online: www.loc.gov/rr/frd/pdf-files/NarcsFundedTerrs_Extrems.pdf

UN Security Council Counter-Terrorism Commission, 'Paris attacks showed role of small transactions in terror finance; UN meeting hears’, 15 April 2016. Online: www.un.org/ sc/ctc/news/document/paris-attacks-showed-role-of-small-transactions-in-terrorfinance\%CD\%BE-un-meeting-hears/

U.S. Department of State, 'Foreign Terrorist Organizations’, Bureau of Counterterrorism, s. a. Online: www.state.gov/foreign-terrorist-organizations/

U.S. Government Printing Office, 'Three Years after September 11: Keeping America Safe. U.S. Senate Committee of Justice'. Testimony of Denis M Lormer before the Senate Judiciary Committee, Subcommittee on Technology, Terrorism, and Government Information, 2003. Online: www.govinfo.gov/content/pkg/CPRT-107SPRT83870/html/ CPRT-107SPRT83870.htm

U.S. Government Publishing Office, ‘A Dangerous Nexus: Terrorism, Crime, and Corruption”. Hearing before the Task Force to Investigate Terrorism Financing, 21 May 2015, U.S. House of Representatives. Online: www.govinfo.gov/content/pkg/CHRG-114hhrg95071/ html/CHRG-114hhrg95071.htm 